\title{
LIST OF POSTERS
}

\section{Session on Solar Neutrinos and Models}

\begin{tabular}{|c|c|c|}
\hline ALEXEYEV & Evgenii & $\begin{array}{l}\text { Search for solar flare neutrinos at the Baksan INR } \\
\text { underground scintillation telescope } \\
\text { (with L.N. Alexeyeva, A.E. Chudakov, I.V. } \\
\text { Krivosheina) }\end{array}$ \\
\hline BONETTI & Silvia & $\begin{array}{l}\text { BOREX : a future solar neutrino experiment at } \\
\text { LNGS } \\
\text { (with the Boron Solar neutrino Collaboration) }\end{array}$ \\
\hline BOUQUET & Alain & $\begin{array}{l}\text { WIMPs in Stars : an analytical approach } \\
\text { (with J. Kaplan,F. Martin, G. Raffelt, } \\
\text { P. Salati, J. Silk) }\end{array}$ \\
\hline BOUQUET & Alain & $\begin{array}{l}\text { WIMPs and solar evolution codes } \\
\text { (with Y. Giraud-Héraud,J. Kaplan,F. Martin,C. } \\
\text { Tao,S. Turck-Chièze) }\end{array}$ \\
\hline CHERRY & Michael & Solar neutrino backgrounds : atmospheric effects \\
\hline DZIEMBOWSKI & W.A. & $\begin{array}{l}\text { Solar model from Helioseismology and the Neutrino } \\
\text { flux problem } \\
\text { (with A. Pamyatnykh and R. Sienkiewicz) }\end{array}$ \\
\hline de BELLEFON & Alain & Indium \\
\hline FAULKNER & John & WIMPs in the Sun and other stars \\
\hline FINZI & Arrigo & $\begin{array}{l}\text { Non-Baryonic matter from Halo and the solar } \\
\text { neutrino problem (with A. Harpaz) }\end{array}$ \\
\hline GERBIER & Gilles & Experimental search for Cosmions \\
\hline GEROYANNIS & Vassilis $S$. & Rotating Viscopolytropic Stellar Models \\
\hline GRANDPIERRE & Attila & $\begin{array}{l}\text { Nuclear instability of the Sun and the Neutrino } \\
\text { problem }\end{array}$ \\
\hline HAHN & Richard L. & ${ }^{71}$ As as a test of the Gallium neutrino detector \\
\hline HAUBOLD & Hans $\mathbf{J}$. & $\begin{array}{l}\text { Fourier spectrum analysis of the solar neutrino } \\
\text { capture rate (with E. Gerth) }\end{array}$ \\
\hline KOCHAROV & Grant E. & $\begin{array}{l}\text { 1) }{ }^{3} \mathrm{He} \text { isotope and the solar neutrino puzzle } \\
\text { 2) Cosmic ray modulation during the Maunder } \\
\text { minimum } \\
\text { 3) Increased counting rates in Davis' experiment and } \\
\text { nonstationary processes in the Solar Substance } \\
\text { (with G. Kovaltsov, I. Usoskin) }\end{array}$ \\
\hline MAK & Hay Boon & The Sudbury Neutrino Observatory \\
\hline MOREL & Pierre & $\begin{array}{l}\text { Updated stellar evolution codes and the standard } \\
\text { solar model } \\
\text { (with J. Provost, G. Berthomieu) }\end{array}$ \\
\hline
\end{tabular}




$\begin{array}{lll}\text { NOELS } & \text { Arlette } & \text { Galactic cosmions and solar models } \\ \text { PLAGA } & \text { Rainer } & \begin{array}{l}\text { Violations of the Pauli principle and the interior of } \\ \text { the Sun. }\end{array}\end{array}$

$\begin{array}{lll}\text { RAISBECK } & \text { Grant } & \begin{array}{l}\text { Detection of }{ }^{7} \mathrm{Be} \text { neutrinos from a lithium solar } \\ \text { neutrino detector }\end{array} \\ \text { RAYCHAUDHURI Probhas } & \begin{array}{l}\text { Time variation of solar neutrino flux and its } \\ \text { implication in stellar structure }\end{array} \\ \text { SCHROEDER } & \text { Norman } & \begin{array}{l}\text { The Molybdenum - Technetium Solar Neutrino } \\ \text { Experiment } \\ \text { (with K. Wolfsberg, D. Rokop). }\end{array}\end{array}$

TURCK-CHIEZE Sylvaine On the accuracy of solar modelling (with M.Cassé)

ZATSEPIN George Present status of Baksan gallium detector.

\section{Session on Helioseismology and Diffusion}

$\begin{array}{lll}\text { ANGUERA } & \text { Montserrat } & \begin{array}{l}\text { An attempt to identify low l - low n solar acoustic } \\ \text { spectrum } \\ \text { (with P.L. Pallé, F. Perez, T. Roca Cortes) }\end{array} \\ \text { APPOURCHAUX } & \text { Thierry } & \begin{array}{l}\text { Observation of low-degree solar modes in intensity } \\ \text { fluctuation } \\ \text { (with B. Andersen) }\end{array}\end{array}$

\section{APPOURCHAUX Thierry}

BALMFORTH Neil

BEL Nicole

BROWN Timothy M.

CACCIANI Alessandro

$\operatorname{COX}$

DELACHE

DZIEMBOWSKI Wojciek

GABRIEL

GOUGH
Maurice

Arthur N.

Philippe J.

Douglas $\mathrm{O}$.
Conceptual design of an instrument dedicated to low-1 and low-frequency solar modes observation

Mixing-length theory and the excitation of solar acoustic oscillations (with D.O. Gough)

On the influence of the magnetic field on the solar oscillations

An inverse method for p-mode scattering measurements.

Use and Performance of the Magneto-Optical Filter for low-l mode measurements (with D. Ricci and P. Rosati)

Period and stability of solar g-modes

Wavelet analysis of long term solar variability

Magnetic field in the Sun's interior from oscillation data (with P.R. Goode)

The 1 dependent part of $D_{n l}$ and the structure of the solar core

Sensitivity of solar eigenfrequencies to the age of the Sun (with E. Novotny). 


\begin{tabular}{|c|c|c|}
\hline HILL & Frank & $\begin{array}{l}\text { Mapping flows in the Solar convection zone using } \\
\text { oscillation ring diagrams. }\end{array}$ \\
\hline JEFFERIES & Stuart & Rotational splitting of the low degree solar p-modes \\
\hline KOSOVICHEV & Alexander & $\begin{array}{l}\text { Using helioseismological data to probe chemical } \\
\text { composition in the solar core. }\end{array}$ \\
\hline LABONTE & Barry & $\begin{array}{l}\text { Acoustic Imaging Through the Sun } \\
\text { (with D. Braun and T. Duvall) }\end{array}$ \\
\hline LAVELY & Eugene & Testing mixing length theory with helioseismology. \\
\hline LAVELY & Eugene & $\begin{array}{l}\text { The Influence of Gary Glatzmaier's Convective } \\
\text { Flow model on Solar Oscillations } \\
\text { (with M. Ritzwoller) }\end{array}$ \\
\hline PALLE & Pere L. & $\begin{array}{l}\text { Variations of the low } 1 \text { solar acoustic spectrum } \\
\text { correlated with solar cycle } \\
\text { (with C. Regulo, T. Roca Cortes) }\end{array}$ \\
\hline PROVOST & Janine & $\begin{array}{l}\text { Nonequidistent spectrum of gravity modes } \\
\text { (with G. Berthomieu, E. Gavryuseva, } \\
\text { W. Gavryusev). }\end{array}$ \\
\hline REGULO ROUEZ & Clara & Splitting of p-modes of low degree \\
\hline RHODES & Edward J. & $\begin{array}{l}\text { Evidence for degree-dependent variations in the } \\
\text { frequency splittings of solar sectoral p-modes } \\
\text { (with A. Cacciani, S. Korzennik) }\end{array}$ \\
\hline ROCA CORTES & Teodoro & $\begin{array}{l}\text { The low frequency solar velocity spectrum } \\
\text { (with P. Palle). }\end{array}$ \\
\hline THOMPSON & Michael & $\begin{array}{l}\text { Solar rotational splitting measurements } \\
\text { (with S. Tomczyk) }\end{array}$ \\
\hline YERLE & Raymond & Limb darkening Oscillations : Solar and Terrestrial \\
\hline YIOU & Françoise & $\begin{array}{l}\text { Cosmogenic }{ }^{10} \mathrm{Be} \text { as a probe of time variations in } \\
\text { solar activity }\end{array}$ \\
\hline ZHUGZHDA & Yuzef & $\begin{array}{l}\text { 1) Observations of intensity fluctuations of } \\
\text { low-1 modes } \\
\text { 2) Seismology on space observatory coronas } \\
\text { (with N. Lebedev and I. Kopaev) } \\
\text { 3) On the possibility of } 160 \text {-min resonance } \\
\text { oscillations in the earth atmosphere }\end{array}$ \\
\hline
\end{tabular}

\section{Session on Convection, Dynamo and Transport}

$\begin{array}{lll}\text { ALLKOFER } & \text { Otto Claus } & \text { First results from the HEGRA project } \\ \text { ARTZNER } & \text { Guy } & \text { Solar photographic astrometry } \\ \text { BALLESTER } & \text { Jose Luis } & \begin{array}{l}\text { Periodicities and asymmetries in solar activity } \\ \text { (with G. Vizoso) }\end{array}\end{array}$

BISNOVATYI-KOGAN Gennadii Angular velocity distribution in convective regions 
BOCHSLER Peter

BRANDENBURG Axel

RUSIN V.

BRUECKNER Guenter

CALLEBAUT Dirk K.

CHAN Kwing Lam

CHRISTENSEN-DALSGAARD J.

COPLAN

Michael

COURTAUD Didier

DÄPPEN

Werner

DERMENDJIEV Vladimir

DEUBNER

Franz-L.

DONATI

J.F.

FOING

Bernard

FORESTINI

Manuel

GRANDPIERRE Attila

KOTOV

LIPUNOV

Vladimir

LUSTIG

Günter
The abundance of $3 \mathrm{He}$ in the solar wind - a constraint for models of the Solar evolution (with J. Geiss, A. Maeder)

The nonlinear solar dynamo and differential rotation (with D. Moss,G. Rudiger,I. Tuominen).

Large-scale distribution of the global magnetic field, green corona and prominences during an extended activity cycle

(with V. Bumba and M. Rybansky)

Intermediate-term solar periodicities : 100 to 500 days

1) Generation of magnetic fields in the sun.

2) Sunspot cycle from solar oscillations

Differential rotation around Solar Convection Zone

The depth of the Solar Convection Zone (with D. Gough and M. Thompson)

The abundance of minor ions in the solar wind and comparison to solar abundances (with K. Ogilvie, P. Bochsler, J. Geiss)

The influence of metallicity on opacity coefficients (with G. Damamme,E. Genot,M. Vuillemin, S. Turck-Chièze)

The equation of state of the solar interior : a comparison of results from two competing formalisms (with Y. Lebreton, F. Rogers)

Solar activity in the past and the problem of solar dynamo (with Y. Shopov, G. Buyukliev)

Comment on Solar Convection

Zeeman-Doppler imaging : a new option for magnetic field measurement in active solar-type stars (with M. Semel, F. Praderie)

Probing stars with magnetic activity signatures (with S. Char and S. Jankov)

New constraints on the solar $\mathrm{Li}$ and $\mathrm{Be}$

Explosive convection at the solar core

Pulsation of the sun as a probe of 22-year cycle and central solar core (with T. Tsap).

Magnetic field inside the sun and magnetic properties of collapsed stars

Solar meridional plasmas motions from 1982 until 1986 (with H. Wöhl) 


\begin{tabular}{|c|c|c|}
\hline MERRYFIELD & William & $\begin{array}{l}\text { Azimuthal convective rolls and the subsurface } \\
\text { magnetic field }\end{array}$ \\
\hline MONTESINOS & Benjamin & Magnetic field pattern and transtion region activity. \\
\hline MORROW & Cherrilynn & $\begin{array}{l}\text { Determining solar asphericity by asymptotic } \\
\text { inversion }\end{array}$ \\
\hline RÄDLER & Karl-Heinz & $\begin{array}{l}\text { On the non-axisymmetric magnetic field modes of } \\
\text { the solar dynamo } \\
\text { (with A. Brandenburg, I. Tuominen). }\end{array}$ \\
\hline ROXBURGH & Ian $W$. & Mixing in the solar interior \\
\hline RUSIN & V. & $\begin{array}{l}\text { 1) Periodicities in the green corona }(530.3 \mathrm{~nm}) \\
\text { brightness for the sun as a star (with J.Zverko) } \\
\text { 2) Large scale development of the green corona and } \\
\text { prominence occurences (with M. Rybansky) }\end{array}$ \\
\hline SYLWESTER & Janusz & $\begin{array}{l}\text { Possible scenarios for build-up of Calcium } \\
\text { abundance differences in flares } \\
\text { (with B.Sylwester, R. Bentley) }\end{array}$ \\
\hline TOOTH & Patrick & $\begin{array}{l}\text { A new test on nonlocal mixing-length theory } \\
\text { (with D.O. Gough) }\end{array}$ \\
\hline TSCHARNUTER & Werner M. & Instabilities in the Early Protosun \\
\hline VIGNERON & Caroline & $\begin{array}{l}\text { Angular momentum transport in pre-main sequence } \\
\text { stars of intermediate mass } \\
\text { (with C. Catala,E. Schatzman,A. Mangeney) }\end{array}$ \\
\hline VUILLEMIN & Michel & Nouveaux calculs d'opacités spectrales \\
\hline
\end{tabular}

